Helen Milte Bastow

\title{
Dialogues with a body called the research journal
}

\begin{abstract}
Recording the mystery that accompanies the process of writing is almost impossible. What can be seen are traces - the collected patterns, images, and motifs from an unconscious research, souvenirs of the semiotic world, which are collected in the process called the research journal. As such, the journal's facility to hold onto primitive transactions, of rhythmic and imaginary language, the unconscious exchanges between the novelist and herself, can be reminiscent of the imaginary exchanges within the maternal world, and in object relations. This paper will describe the enactment of a body dialogue, in the journal's holding onto, and 'projective identification' of, traces of unconscious fantasy, imaginary language and emotion, left behind in the daily pages of the novel. The paper will document this intimate and poetic language, of a body called the research journal, as it contrasts with the more abstract, public and [phal]logocentric order of the academic thesis. In the course of the paper I hope to express something about my developing realisation that the most valuable contribution I might make to the fields of writing and creative arts are possibly contained in this unofficial document, and its particularly intimate, critical engagement with my research. I will posit that because journal writing theorises from practice - and in my discipline, from the practise of writing - the research journal should be considered a most valuable and rigorous resource.
\end{abstract}

There is no Country but childhood's. - Roland Barthes [1]

Spend time down by the water. Listen to the water. - Yvonne Koolmatrie, Ngarrindjeri weaver and Cultural Educator [2]

Through the peninsula system, there's huge midden mounds which tells us a lot about our history of the people, our people who lived on there. For ten years or more, Tom and I have been bringing groups over here, showing them the peninsula, walking it, and looking at the midden mounds. We tell non-Aboriginal people who visit us that's just not an Aboriginal problem to look after these sort of things. Those things hold a lot of history for us, us as Australians, not us as just Ngarrindjeri people alone. - George Trevorrow, Ngarrindjeri Cultural Historian at Camp Coorong, Centre for Race and Cultural Relations [3]

You're my murawee. - Stephanie Gollan, Ngarrindjeri Cultural Instructor and weaver [4]

Explore thyself! / Therein thyself shalt find / The Undiscovered Continent Emily Dickinson [5] 
The Coorong is a significant landscape of approximately 2000 square kilometres in the southeastern region of South Australia, covering a large proportion of the traditional territory of the Ngarrindjeri People. It is a landscape which has been described variously as an area of Aboriginal archaeological deposits that are unequalled in their volume and vastness; an irreplaceable resource; an environmental landscape of rich coastal wetlands and sand dunes; a National Park; a dune and water system; a series of companion lagoons and wetlands near the Lower Lakes of the River Murray; a saline estuary more than 100 kilometres in length, separated from the Southern Ocean by the high sand dunes of the Younghusband Peninsula, which begins adjacent to the mouth of the Murray River in South Australia.

As a writer I have been exploring my old relationship with this place known as The Coorong, and coincidentally revisiting another place, The Coorong of my imagination. As I improvise the landscape of my fiction novel in progress [6], the novel's story, written after The Coorong, takes me into another unconscious landscape, the country of my childhood.

Through the early childhood of the four years spent writing and researching my creative thesis, I have travelled back and forth to this palpable 'landscape journal' known as The Coorong, and from it discovered the world and concerns of my novel and its inhabitants.

The Coorong is a deeply strange, spiritual land, of which the Ngarrindjeri People [7] are the living custodians. One of the important directions for my research was to meet with Ngarrindjeri people and acknowledge the longevity of their relationship with the landscape of my novel and my childhood. I asked for a meeting because I wished to inform the Indigenous custodians of the intentions of my creative project involving their landscape. I wished to inform myself of the Ngarrindjeri Dreaming, to illuminate my imaginary narrative. I sought a critical discourse because I hoped that the custodians of my formative landscape would tell me if what I was writing was authentic in its creative visualisation of wilderness as imagination.

As a writer I was deeply interested in the possibility of a conversation with the original landscape writers of the country of my childhood, about the narratives that might be improvised from that place. I also wanted to be sure that what I was writing - the way that I was telling the landscape - was not offensive to the Ngarrindjeri custodians. I wanted to check that the practical aspects of my work, its uses of motif and symbol for example, were not considered inappropriate for the region that has been the Ngarrindjeri's homeland for six thousand years.

\section{Country and Body}

Writing the novel has taught me, as I have progressed, about the layers of language and memory, and childhood. And about other languages, perceived from experience, carried in the memory of the body. In his beautiful essay "La Lumière du Sud-Ouest", [8] Roland Bathes writes about this record held within the body's knowing:

To read a country is first of all to perceive it in terms of the body and of memory, in terms of the body's memory. I believe it is to this vestibule of knowledge and of analysis that the writer is assigned: more conscious than competent, conscious of the very interstices of competence. That is why childhood is the royal road by which we know a country best. Ultimately, there is no Country but childhood's. [9]

Julia Kristeva also writes about going back, way back in time, to the vanishing point of Freud's royal road to the unconscious. Kristeva talks about the "imaginary", and the "semiotic" state, before we become separated from our mother, before we become "subjected to words". A fantasy time, of sound images, of transfers of messages, other than language, other language, between the mother and child. Kristeva talks about the loss of this voice when we enter the "banal ordered world of logical language - of social communication - when the first semiotic language is repressed". She observes, in many, depression where the absolute killing off that imaginary voice has occurred. She encourages such sufferers to go searching for the archaic imaginative contact with the maternal body that has been forgotten. [10] 
This "search" for an "archaic imaginative contact" speaks directly to the searching for lost landscape that is at the heart of my novel:

... what she knew but could not say, was that she loved the paradox of her
instability being made to feel at home there, in that outside place, that
outside coming in. So that the looseness of her inland sea felt typical there,
even connected, to the natural scenes of the art of undoing. Like the emptied
dumps of Neelie, washing-in her wake at the side of the road, closing-in her
passage through the spell of the sand dune mountains. She dreamed and
trailed her somewhat smaller hand in the soft and sandy foam mounds of
dissolving time. To her surprise, in their lightnesses, the shapes seemed like
only yesterday. (Milte Bastow, Dissolve, novel in progress)

The novel has the working title of Dissolve. My writing process moves back and forth between the novel and the research journal's observations, and between the journal and the creative exegesis. All of my writing explores a relationship between landscape, body and language. The exegesis researches through a critical engagement with a combination of psychoanalytic, feminist and cultural theories, which surround the study of fantasy, subjectivity and the practice of words. The novel and the journal speak by the means of a more mysterious meditation or language.

As a writer I am happiest when working with this latter, wild language - the language of the landscape of my imagination. The sessions when I'm remembering what the landscape felt like when I was little, when its form was all I had. Its originality was like nothing else, its shapes were my toys during the days spent swimming in its waters, fresh and salt, making underground caves in its damp dunes that always smelt like rainwater, even in summer. [11] It was a relationship of my body, a language perceived in the memory of my body. For most of my life I've looked and listened for something that can match it, replicate it. As yet, I still haven't found it...

When I began the novel I intuited the need to keep the journal. I felt that I was about to leave on a journey, which would necessarily involve going through an experience of not knowing where I was. Milan Kundera's talisman for writers taken from his lonely planet guide to the novel [12] had prepared me for that much: "to have as one's only certainty the wisdom of uncertainty." [13]

As a safeguard I filled my suitcases with the faces of the books and the critical essays that have tutored me for making the journey - all the letters home from the extraordinary travellers. But as much as any documented experience that I could take with me, I still felt that I needed the support of a place to come to, a base camp in the wilderness, some where I could locate myself, within that space of not knowing.

So it began. Like a child at a typewriter, who writes her name, lower case, because she has nothing else to write yet, I wrote inside the front cover of a blank journal:

Learning to be alone. Journal to accompany me on this adventure. February 1999. [14]

\section{Listening to the water}

Creative writing is the ability to transpose the chaotic and imaginative relationship that accompanies a journey, bring something of its wilderness back into our daily lives. Searching for our story is often a searching for that lost voice of the first imaginary experience. It involves a returning, to reconcile a separation, a longing to and from our (m)other, our place of origin. Kristeva argues, "Our experience of the semiotic memory - the mother and infant holding (chora) - produces poetry in language. If we don't hear it, or we forget it as part of ourselves, we can become strangers to ourselves." [15] On the other hand, creativity can restore our sense of the pleasure of our original relationship. When we remember this maternal relationship, we remember the possibility of creation. Kristeva posits, "Every type of creation, even if it's scientific, is due to the possibility of opening the norms, towards pleasure, which refers to this archaic experience with a maternal pre-object." [16] 
So journeying, listening to or for story, is about the search for something indigenous to us, something imaginative and, possibly, forgotten. I've been listening for invisible words and stories, under my breath, for most of my life. Listening to them in silence, in the nothingness of childhood, the work of childhood - the work of becoming a writer - then listening to the other writers, to what the other storytellers have heard and spoken for me.

Now I am listening to and remembering the lost narrative of the landscape of my childhood, The Coorong. Travelling the problematic road back to what I am [unconsciously] trying to remember to tell myself. Seeking out what I need for my novel, the story within my imagination - a voice, a theme, a motif, a situation, a character - all of the above, speaking under my breath; the threads of my fable, latent words, material from origin.

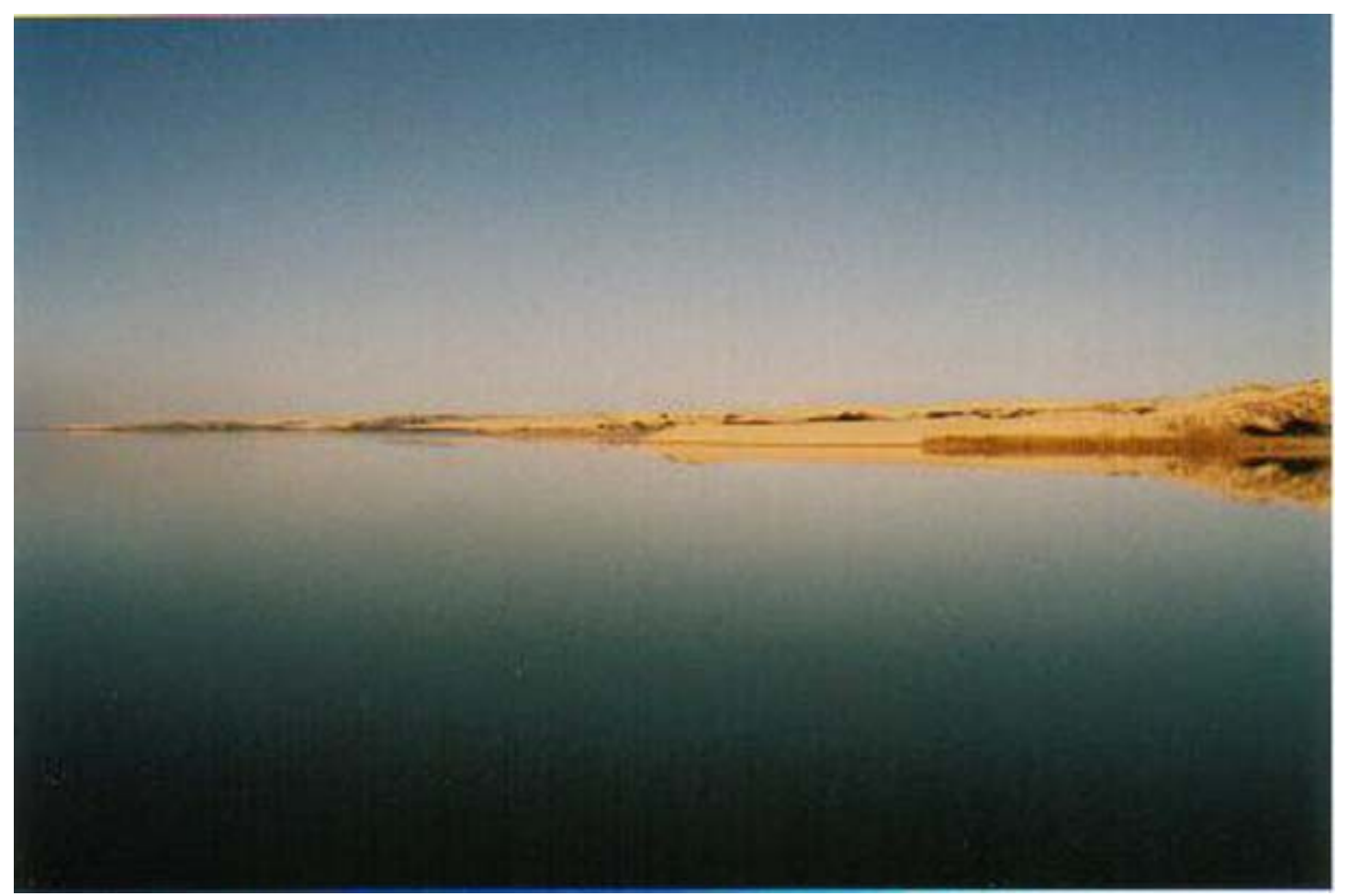

The Dream [17]

The day before I met with the first of my Ngarrindjeri contacts based in Adelaide, I began my research by walking in the field alongside my childhood experience in the silence of The Coorong dunescape. Absorbing and retracing my history, memories of the special, never forgotten days, when our family made the crossing over the lagoon to the hummocks beyond. And at the same time walking beside another adult experience of tracing the available history of the Ngarrindjeri People, culture resting extant in the landscape. Ngarrindjeri history that was only available to me on another level of consciousness as a child growing up in the 1960s culture post the State and Commonwealth Policy Conference on Assimilation [1951]. It was during this reflective field trip, in the presence of myself as child and adult, that I stumbled upon a significant detail, which moved me profoundly. It is a detail that has confirmed my desire to continue with the project of my research and my novel.

Returning from a long guided walk [18] into the dunelands, an experiential engagement of the kind that can make you feel utterly inadequate as a writer using English to talk about landscape, I came across a small shelter, which had been constructed since my childhood by the traditional owners. In the hut there was a description of the Ngurunderi story [19], my first physical encounter with the Ngarrindjeri Dreaming and its significant motifs.

Until that moment in the shelter I had unwittingly been made ignorant of the Ngarrindjeri Dreaming. During the 1960s the primary school curriculum of my local State School denied its students any exposure to the otherness of Indigenous Aboriginal culture. I was not given the opportunity of an education in the Dreaming stories of the Ngarrindjeri children who attended my school and were my friends, because their culture was in the process of being actively erased, or Assimilated. My childhood experience was not uncommon in my town of Meningie. In her paper "Veena Gollan's Story", Ms Veena Gollan, a woman born in 1952 on sacred Ngarrindjeri tribal land at Raukkan [formerly Point McLeay], refers to her experience of the Meningie Area School thus: 
As a young child I did not know, or understand, the laws imposed on Aboriginal people... It was the early fifties and the Assimilation policy stated that all Aborigines were expected to eventually attain the same manner of living as other Australians and to live as members of a single Australia.

It was at this time our family moved away from Point McLeay [Raukkan] to the local township of Meningie... Going to the Meningie school, the teachers certainly did not know or understand Aboriginal issues at that time...Curriculum did not reflect accurate information about Aboriginal people, simply because Aboriginal people weren't invited to participate in the development of the curriculum. [20]

Despite my parents' awareness of, and compassion for, the impeded culture of their Indigenous friends and neighbours, their knowledge, such as it was, did not extend to discussions with their second youngest child during the years 1961-1968. No one explained to her that the Aborigines of her town were largely Ngarrindjeri people, a group originally numbering 3000 [21], who had been dramatically evicted from fertile tribal lands in The Coorong. The young girl had no access to an available local Ngarrindjeri history. Her town was not yet in possession of a museum. She was not aware of any Aboriginal lore yet available, published, in any form, in any local cultural or historical references.

Her - my - our writing is often about this experience, this story, of the isolation from information. Mine is a novel based on lack. I remember, as a child, perhaps because of that missing information, the feeling of perceiving something important that was missing, or invisibly present, in the empty landscape that surrounded me.

Braille. Feel it seeingly. (Milte Bastow, Research Journal in process, 5 April 2000)

There is also another - more recent - explanation for my ignorance, and it is more personal. As part of my writing and research I did not seek to investigate the Ngarrindjeri Dreaming earlier because I had a strong desire to write from this childhood instinct, and in isolation from all else but my imagination and the other information it had given me the child. I wanted to begin writing from a direct vocabulary, formed out of the 'introjection' [22] of the subversive language of The Coorong landscape that had surrounded and worried my imagination as a child. I did not want to pre-empt my other story, which my experiential knowledge of the landscape had already told me. Perhaps it was for this reason, even up to that day of 1 July, mid-winter 2001, and the guided eco-tour walk on The Coorong hummocks, that I remained reticent about entering an information shelter, because I still wanted to explore the desire of a lack.

\section{Arrival}

After a day spent walking in the silence of the dunescape I found myself alone within the Ngarrindjeri's shelter, in the presence of an extant Dreaming. As I read the story I realised that the way in which I had imagined The Coorong in Chapter Two [23] of my novel was significantly related to aspects of the Ngarringjeri Dreaming story of Ngurunderi. I had unconsciously used two of the most important motifs of the Dreaming for The Coorong to describe the place of $m y$ dream: the central figure of a "black man", or "Ngurunderi", and the "Milky Way", the "resting place of Ngurunderi". The realisation of this unconscious connection was a powerful moment, which I felt in my body, as an emotional shock - or a combination of awe and relief.

After years of creative wandering I felt received by the landscape of my imagination, that by trusting the journey [and the journal] of a mysterious language path - a "Dreaming path", as Lillian Holt [24] might call it - and drawing upon my unconscious, which was informed by a childhood spent playing within that other language and its narrative, I had in fact made essential choices. It was a moment that seemed to enact Reconciliation, a moment that expressed to me the failure of Colonialism to eradicate an Indigenous culture extant in the landscape. My experience also suggested to me the level of trust required to enter into other ways of telling and understanding that is a pre-requisite for Reconciliation. 
The experience in the shelter was also a profound moment of personal reconciliation, of reconnecting the child with the adult, giving me a sense of arrival that came from the impalpable and innocent feelings of childhood being palpably placed in my adult writing. [25]

Outside, the fresh night wind lit up her eyes and made them shine. In the daylight Neelie had grey-green eyes. They were almond-shaped and wide set in her face. A strong face, with thick eyelashes and natural brows. When she was sleepy she had a habit of looking young, almost childlike. Tonight, with her head thrown back searching for the available skylight, her face was as pale and as smooth as the freshest dune, the human face of the dune, prone, skyward facing.

Stepping along the flat path the sand pressed back through the tight skin of her man-made soles. Twiggy storks of ground cover snapped beneath her, like when she was little and wore cotton nighties to bed, the ones she got all the Christmases in a row. She felt like a big girl, wobbling precariously among the floating sea-grapes of the random beach garden. Some of their faux fruits popped open, sounding their channel warning. With the crunch of shell-grit to navigate by, she somehow crossed the ambiguous front lawn to go round the back of the night-time holiday house. Then, as she turned the corner of the shack, circumnavigating the outrigger water-tank, she sensed it. A presence of something. Just off the edge of her waking. Its being made all of the small hairs on her body stand up ready. Neelie felt it before she could make it out.

Just there, already close. At the tip of the invisible point of the isthmus, just beyond the floating edge of Frank's world. Hard to read in the dark, at the edge of the vagaries of her night blindness, still more a sense of presence than of seeing. The vaguest outline. Its silent back. Its black body, too perfectly camouflaged by the missing moonlight, revealing itself more by its shadow, its openness eclipsed behind the night. Neelie had a feeling of being drawn. The space was waiting, lying in wait. It knew she would come. It always knew she would wake up and come out to find it.

Sleepwalking towards the dissolving edge. The stillness becoming more darkly emergent, stronger in its blackness, shining as dull as charcoal now. The smooth black of its distance - unfolding the long sweep straight out ahead, going right over the veil of the water, to reach the ghostly stand of the lunar sandranges on the other side, hard to tell, perhaps a mile away? Then up and down, where the imaginary waterlands came from, as far as the eye couldn't see, a hundred miles, more... It didn't matter. All that space was present, available, there somehow before her. If anything, it's like poetry, Neelie thought in her prayer to herself, her thought clear, like a train of water, a part of the imagination, distilled and fertile, lying at her feet.

The reverie of their exchange kept her standing, for an unknown time, shivering, at the thin edges of the waterline. She wondered. Someone had left the gate open, the way to the cut-off place, the place where you couldn't go, was wide open, possible. And tonight, under the deep water of the winter moonlight, the fluid black before her was less inland ocean stream than painted night sky. Neelie standing in the shallows of the Milky Way.

She could see the light happen intermittently, through the ripples, the dream pathway of the long water stretching back through time, with its potent mixture of animal and mineral and drowned star. Neelie caught herself, with unexpected tears, very old tears. She knew them but could not remember why. They felt like love, for the sudden sleeping body of the arbitrary water, the vast and latent estuarine water she'd left behind, the thought she'd lost. For the joy of not seeing it, and because of that, seeing it, and its difference, perfectly, out of place, shifted. She always knew it was there, she never expected it to matter that much. When she turned to walk back up the short sand beach to the dunny, it was as if she was walking on the moon. (Milte Bastow, Dissolve, novel in progress) 
Still standing in the shelter I looked back with relief at the uncertainty I had experienced about my novel in progress, as recently as that same morning in the field; at the choices, which, until that moment in the shelter, I couldn't reconcile. The artistic decision to have my female lead arrive in The Coorong at night, and see it for my reader for the first time in darkness, when, since childhood, it had been for me a daylight white image, one of bleached sand and salt, desiccated bone and shell, and light on the water; or that I chose to see the living water as a "black man", instead of a zoomorphic image, perhaps a snake or a fish. I had been concerned that the image I felt so sure about, the "black man", might be offensive to the Ngarrindjeri.

In the week 2-5 July 2001, I met with some Ngarrindjeri women in Adelaide. I spoke to them about my apprehensions, and my connections of that day spent in the field of The Coorong. Initially I spoke with Ms Veena Gollan, the Ngarrindjeri Indigenous Education Worker referred to previously in this paper. Ms Gollan is the daughter of Mrs Bertha and Mr Leonard Gollan. I also spoke with Ms Stephanie Gollan, Veena's sister. Ms Stephanie Gollan is a NAIDOC awarded Cultural Instructor and weaver. One feature of Ms Stephanie Gollan's cultural work is to guide tours of the Australian Aboriginal Cultures Gallery at the South Australian Museum.

During both conversations I was reassured by the Ngarrindjeri women as to the aptness of my novel's choices, its uses of motif and symbol for a narrative improvising their Indigenous landscape. It was the image of "the black man" that was immediately recognized by both women. Ms Veena Gollan responded to my story by saying, "We know who that man would be: Ngurunderi. The Dreaming Ancestor of Our People." Ms Veena Gollan went on to talk to me about the history of her People in and around the Lower Lakes of the Murray River and The Coorong. She suggested that I continue with my research by studying the Ngarrindjeri collection and resources held in the Australian Aboriginal Cultures Gallery at the Museum of South Australia. She also suggested that I follow up my interest in imagining The Coorong by contacting Ms Yvonne Koolmatrie, a renowned Ngarrindjeri weaver who was raised in The Coorong landscape. I am grateful to Ms Veena Gollan for her valuable directions. Later in the same week I met and spoke with Ms Stephanie Gollan, who also instructed me about the history of the Narrindjeri People, and about the Dreaming myth of "Ngurunderi", the Ngarrindjeri's "Dreaming Ancestor", the custodian of The Coorong or "Karangk". [26]

The "black man" of my writing became a shared vision that enabled me to enter into a creative discussion with Ngarrindjeri women, educators and artists, about our different and related readings of the landscape that was so particular to all of our individual childhoods. As a writer I found the meetings constructive, challenging and creative. For the child in me, who had been living away from The Coorong for a long time - since I was ten - it was a moving reunion with other women who had grown up playing in the same landscape. What I encountered was a willingness to share in the imagination of a unique landscape we all knew, or loved, variously, or similarly. Perhaps the primary enabling connector for us all, extra to the establishing figure known by the Ms Gollans as "Ngurunderi", was that we all believed in a story that The Coorong had told us.

I was privileged to share in a discourse of other narrative with Indigenous women. We spoke of the mystical and the fantastic in the landscape that informed my creative vocabulary as a child, playing there in the same sand, the same waters; living across the other side of the lake from the women who were now talking to me. I also discussed, with the Ngarrindjeri community so affected, my childhood memory of perceiving a landscape emptied of people, and my associated memory of an unexpressed sense of guilt. Guilt, which the psychoanalytic theorist D.W.Winnicott might argue is natural to a child, and which accompanied the lack of dialogue surrounding the history contained in my childhood. It is my body's memory of that unspoken history, which makes me challenge the policy of the current Howard government, in its refusal to recognise our Nation's collective guilt and responsibility for the removal of Indigenous people, from their fertile homelands, and from their families.

In a discussion of Ngarrindjeri history and mythology [27] the contemporary story of the Ngarrindjeri People's involvement in the politics of gender, knowledge and ownership must be mentioned. I am referring to the events surrounding the Hindmarsh Island Bridge Act of 12 May 1997, and the associated cases put forward by differing groups of Ngarrindjeri women surrounding the protection of sacred places in the Goolwa landscape's mythology. For the purpose of this paper I wish to make the distinction that although Hindmarsh Island remains acute Ngarrindjeri territory, the Goolwa district is not my childhood country. Early in this paper I quoted from Barthes' ultimate essay on childhood and writing, "Ultimately, there is no [other] Country but childhood's." My writing is located in the Country of my childhood, in The 
Coorong, a landscape experienced by me to include a lake at my doorstep; and at my side, a "long, shallow, saline, lagoon separated from the sea by the sand dunes of the Younghusband Peninsula". [This description of The Coorong, another entry in the politics of description, is taken from the South Australian Department of Environment and Planning Reference Guide.] My childhood, and my adult memory of it, did not extend beyond the lake mapped as Lake Alexandrina, a lake so vast it is classed "ocean" by the pilots who cross it. Nor did it extend over the closed concrete barrages that were laid across the lake, to a foreign country: the unknown, unseen [by me] Hindmarsh Island. However contemporary, and however connected to Ngarrindjeri women and their story, that world is another novel, another childhood. Indeed, in the imaginary landscape of my childhood, Hindmarsh Island remained a "secret".

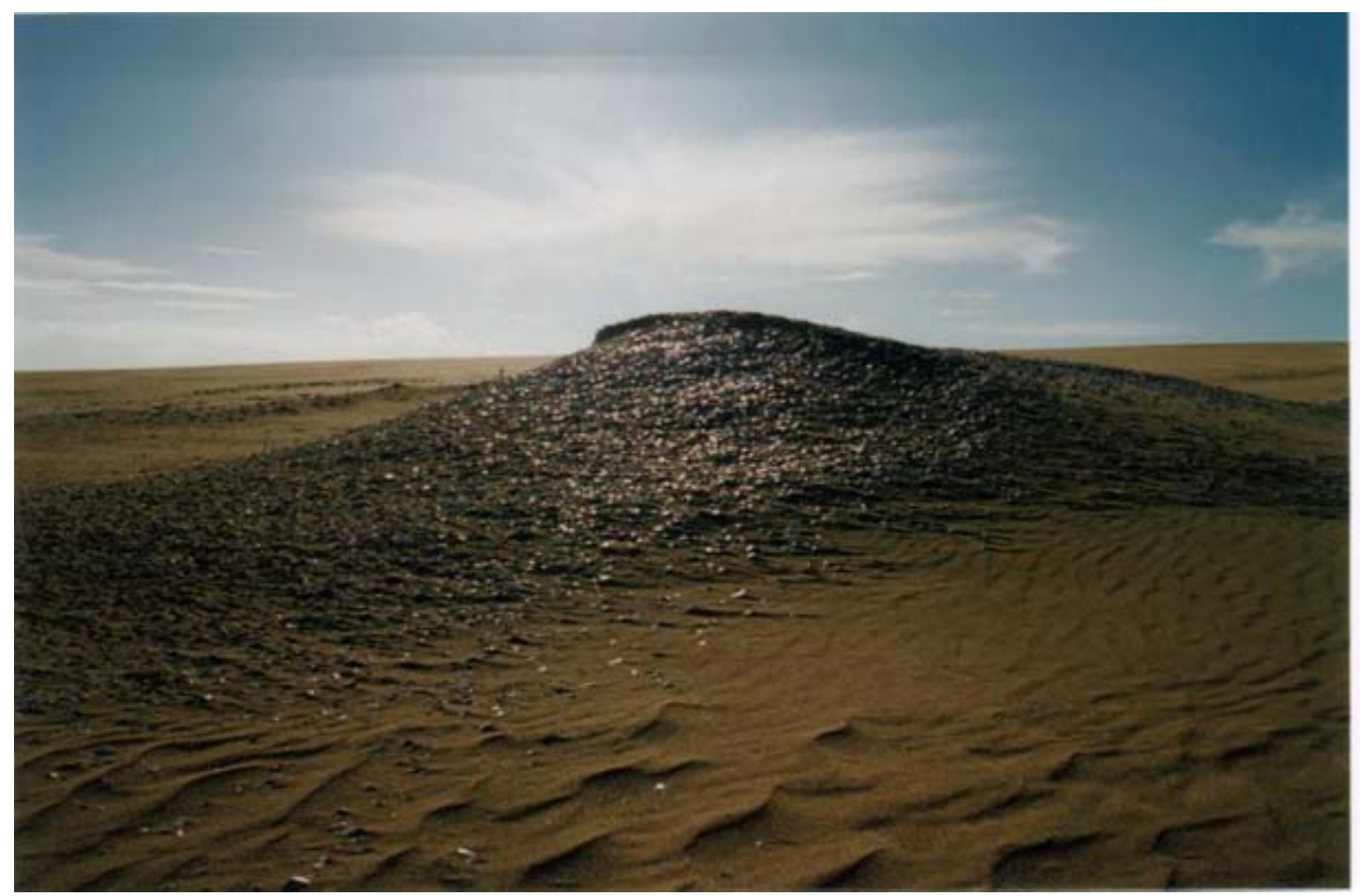

During the experience of The Coorong field trip I revisited the cockle shell middens, original white-coloured kitchens, cultural artefacts 3000 years older than the pyramids, scattered on the beaches that I played on as a kid. I loved the difference of the midden's white colour when I was little. I loved it even more when the previously mentioned Ngarrindjeri weaver and Cultural Instructor Ms Stephanie Gollan asked me - to enable my story weaving of landscape "What colours do you like?" And to make it clearer to a white writer, "Why do you see the midden?" The meeting with Ms Gollan was a gift, for what she perceived about my fiction writing, and for the engaged way she talked to me about my writing and seeing, through the colour system of what she called her "invisible vision": "I see the colour of the landscape. Colour is technology, it's an invisible vision. Colour is looking at you." [28] Ms Gollan talked to me about the visual design for my book, about colours and images, and basket weaving, such as the "coil" pattern original and indigenous to the Ngarrindjeri. She showed me and told me about the Ngarrindjeri "Sister Baskets" [29], with their "two sides the same". She encouraged me to use the image of a "Sister Basket" on the cover of my novel when it is ready for publication; and on the back, a picture of "that green colour, with the two different waters mixing up, [her] favourite place, with the salt and the fresh water coming together".

I told Ms Gollan about my attachment to the landscape and to my favourite play places, and my feelings of being drawn back by the landscape when I stayed away for too long. I talked of a time when I wanted to make poems, out of the sticks and reeds and mosses of my secret places, how I didn't know then that anyone would want to read them. I told her about the times in my adult writing life, going hours out of my way on visits back to Adelaide, and taking my partner, and later our two children, over the years, just to be there with them in that landscape of difference. About the experience, one trip, of finding, and holding, the hard, grey grinding stone left amongst the cockle shells in the midden - the small hand-sized rock, with one 
sharpened edge and five finger prints worn into its palm-shaped dome. About putting it back and seeing it there, still, where it remains in my imagination.

Ms Gollan told me about some of her childhood play spaces such as the "big hill", and about games of hide and seek and daydreaming by the lake. We talked about swimming in the same water, and our shared fear of tigersnakes; the big one that chased her from the sandbank in the lake when she was nine; the same one that chased me from the lake onto the shore near the burning reeds when I was about the same age. At the end of an afternoon spent talking together about landscape and the "technology" of storytelling and weaving, Ms Stephanie Gollan said to me, "You're my murawee."

I asked her, "What does that mean?"

She replied, "My sister. You're my sister." [30]

...The two sleepy women followed each other, single file, picking out the path along the fragile shoreline. Their eyes not particularly drawn to the blank shapes of the moon-coloured rocks, yet aware of them, perhaps, on some deeper level, by some other form of vision, which knew of the latent forms among the shallows.

The stones were well camouflaged to the lake. Their water shapes curved and fleshy, just rising above the water line. Some were prominent, sharp as shoulder blades, which made you wonder how slack water could carve such angles. Others were more open, the yet to be chiseled faces. One had tresses of green waterweed hanging in her eyes. Some stones had their arms full of the tumbled and dried reeds. Some lay about like girls, with the light hair of puberty, just damp, where the water lay between their legs in pools. All the sleeping figures in the rocks, still as they were then, still as they were now, hanging lightly from the spilled-over edges of the water, as children will, attach themselves, loosely, to the edge of the land, and float without trying.

The two walkers looked like children. They found their footing variously across the loose rocky going. Neelie, being tall, and with the added problem of her narrow-heeled boots, had the habit of winding up her arms, to get her balance, even though the stepping-stone was never more than some inches above lake level. She admired the natural composure of her guide. Being shorter, the woman ahead rarely wobbled. She would leap softly onto the least obvious stone, confident of her light footing, even buoyed up by her rotund shape.

They crossed the short beach without speaking, Neelie thought of it as a journey in miniature. When the rocks ran out - abruptly there was an edge with no land, just a dense peninsula of spear-like reeds bursting into the water - Neelie remembered with joy the solution of an invisible opening, a secret place: the reeds separated, and a sandy track appeared. The woman leading her disappeared into the realm of the unknown, a pathway where it seemed she could walk across the water. She moved lightly across the freshsmelling sand path. She passed an emptiness lingering there, a memory of another child playing on a narrow stream of sand, sheltered by the rushes, absorbed by their silence and the blanket lake coming in within their edges. A tunnel of memory, unrolled, flattened out; the unravelled landscape of childhood, as it was, is, will always be, held in the swamp of memory.

Neelie thought deeply, quietly, as she followed, as if she was returning to the body of the water, the fluid space with its unique quiet, its ordinary daily rhythm moving between the intermittent sigh of the waves and longing deep intervals of silence. It was a language told by relationship, only learnt by being within it.

Both women walked and remembered a different pattern, of lost hours spent playing amongst the abundant and natural technology of childhood. Woven there amongst the rushes, nestled into the same curved body of the green 
sleepy lake, lying in the damp bends of its waist, suspended on the resilient bed of the reed bank or in the water below it. Neelie wondered at the mystery of games which seemed to come teasing out of the landscape. (Milte Bastow, Dissolve, novel in progress)

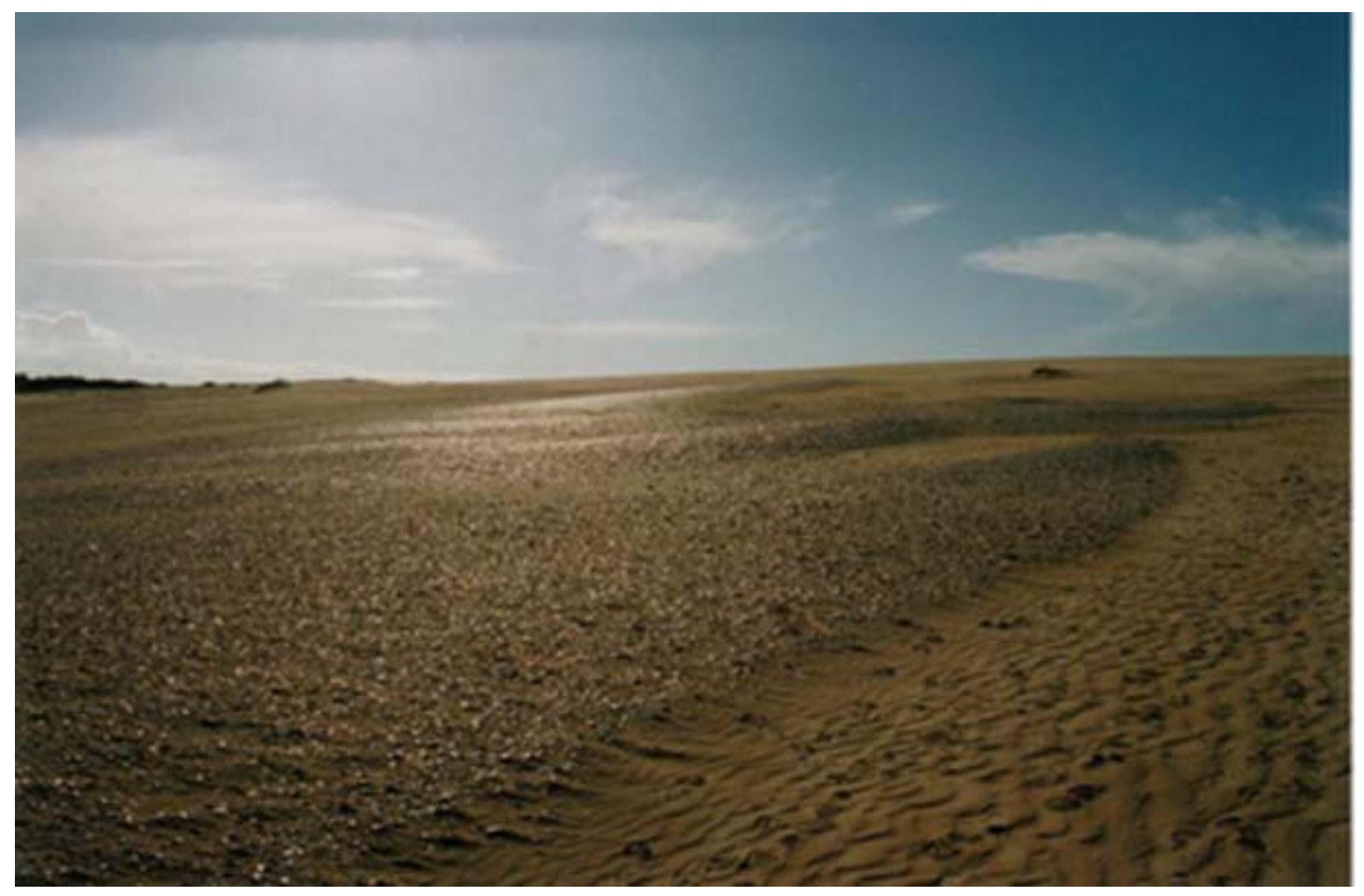

These "unconscious feminine" [31] dialogues, the kind I have been discussing and writing about, conversations about trusting the authenticity of experiential connections, are one and the same with the dialogues of my research journal in process, which seems to write herself, when I trust her to.

Mother and Child. Trust me. I'm a mother. Play, I'll watch. (Milte Bastow, Research Journal in process, 15 March 2000)

Looking at an image like this, I am reminded of Kristeva, and her caution: "Not hearing the semiotic, not giving it room, kills the maternal and the primordial link every subject has with 
the maternal, exposing us to a depression, to a feeling of strangeness." [32] Encouraged by the connections I have made, by the field trip, and the crediting of the other [female unconscious] experiential knowledge I carry inside me, I have learnt to credit the semiotic language of the research journal, and its invaluable "holding" language, its dialogues. For me, the research journal is an object less book than body map. I have learnt to trust the process of going back to it, with necessarily imprecise rhythm, to write out what I haven't said in the novel, in the exegesis, as if it needed another place - a place like The Coorong - for a different dialogue. A place for the responses that emerge from the feminine unconscious, outside the phallogocentric structure, when, consciously, I've switched off from the project of the thesis. These responses are more often suggestions of where I might be, murmurs and images of things, which I become aware of when I am not thinking - under the shower-water, for example - utterings that become known through the body, my body, under the stream of the running water...

Today I'm spending time by the water. Writing there. Taking my time. Time, which stopped there. (Milte Bastow, Research Journal in process, 14 March 2002)

The research journal believes me. It helps keep the content of the novel and the creative thesis alive to its poetic ear - the ear tuned to the subversive or unconscious voice, and what it wants to say. An ear that is aided by the unstructured nature of the writing in the journal, and its process, one of rumination, and talking to yourself, when only your unconscious is listening.

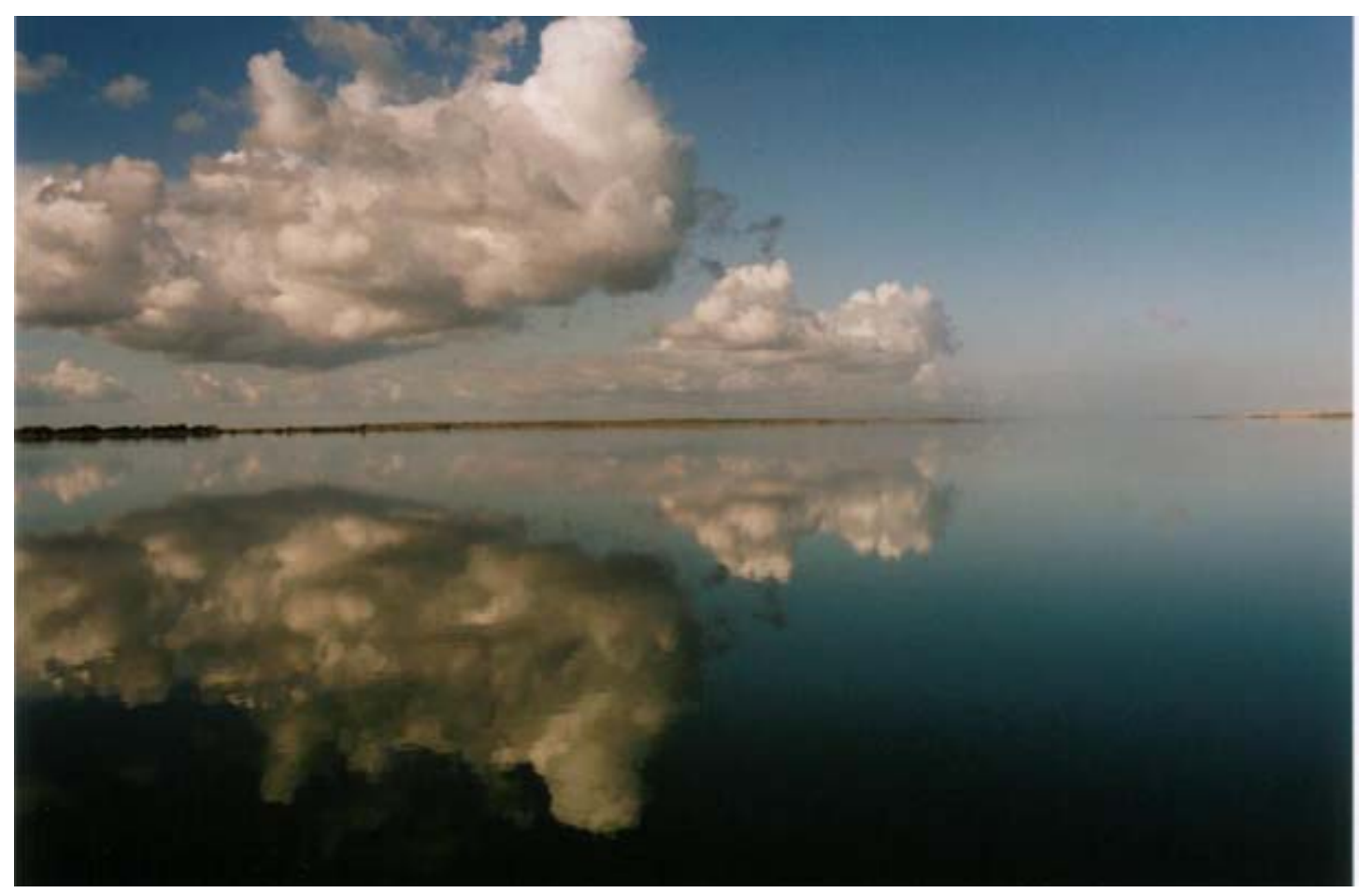

\section{Water colour words}

There is an interesting addendum to this story. I left my study window open for the cat, a window in the low, attic roof above my desk. It rained hard that night. When I woke my research journal was completely soaked. The pages had glued themselves together like a blotter. Many of the variously coloured blue and black inks were washed away, sentences recording the careful icons of my progress into the interior had smudged into each other. I felt a deep sense of loss.

But what is this grief about losing the word path in the book I began "to accompany myself on this journey"? I can see now, now that I've reached this place, looking back four years into the project, that the journal is the childhood of the novel; it is the record of a new space of separation and of silence. To improvise Lacan, it is the record of the space of lack that I desire to, and from. And the journal is a record of myself changing, myself the writer in process, 
deepening my understanding of this craft and the way I can study it, and write about it. Gilles Deleuze theorises about "writing being inseparable from becoming" [33]. Michael Leunig speaks about the process of creating, and of "entering into these things, which change us forever" [34].

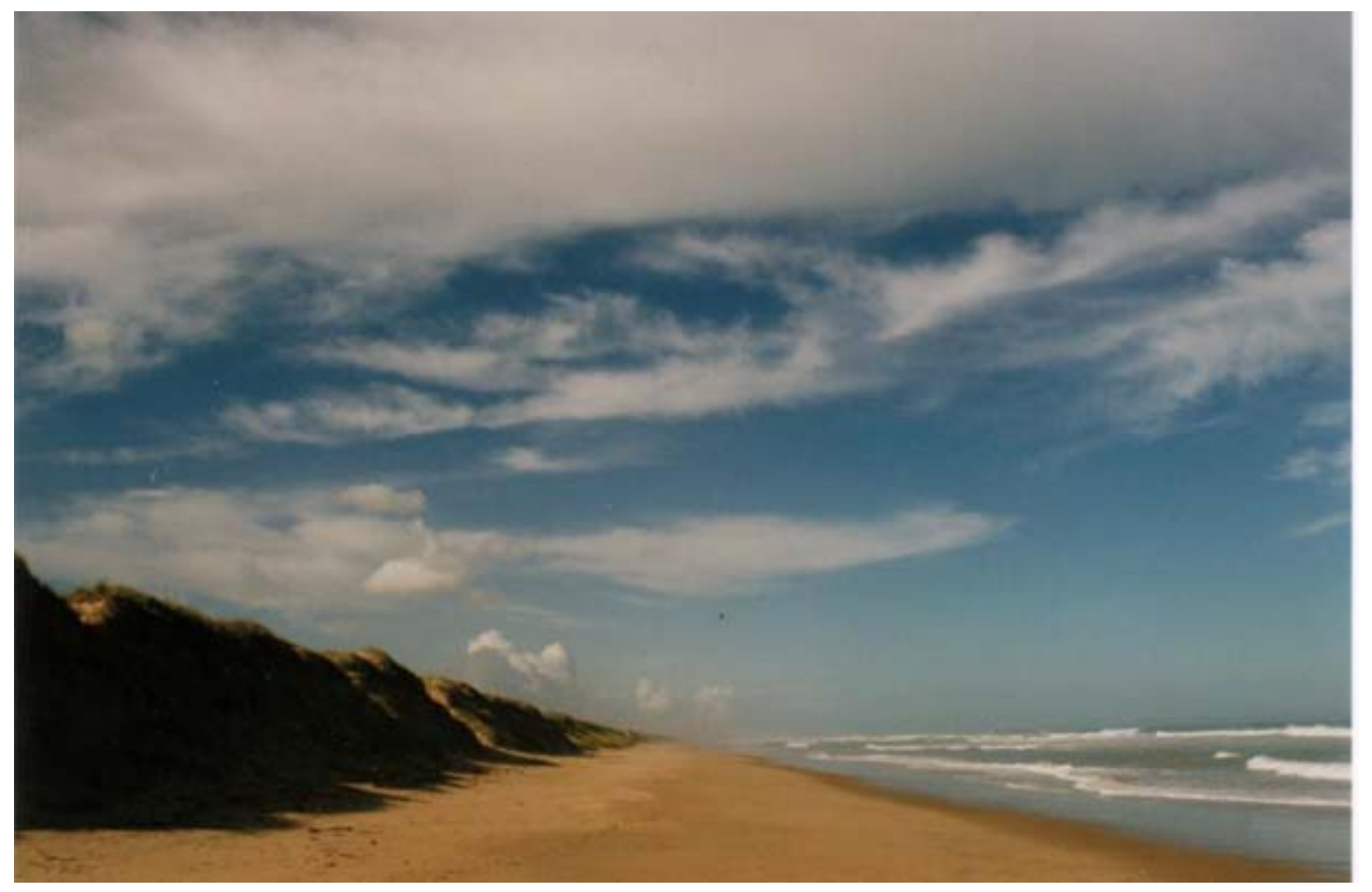

I was taking the poor soggy thing apart, rescuing the pages - laying them as if they were a "poorly" [35] across the still warm bed and the quilt - reading the smudged poetry there, writing that articulates its contribution with love and without fear. I saw in the evolution of the words, the carefully constructed layers of the creative thesis, layers of deep thought, and their blending as the various levels were deposited in their natural form into the pages. The formation of the landscape of the writer: the unconscious, the body, identity, and memory.

The recovered journal went back together again. Once the pages were dry, I collected them with all the other totems from along the way. Feathers encrusted with salt; flowering stone grasses; pieces of abstract poems written in the car going and coming; old poems dragged out of folders, when at last they made sense to me - mementos from the Dream. I reinserted the fragments in their collated moments in the journal. I threaded the red ribbons through the buckled binder holes, and tied them up again with slipknots. And I glimpsed something - a fragment that I'd seen earlier on that drowned, autumn morning in my study, but wasn't able, or yet ready, to acknowledge.

I thought about my creative thesis, and the world of my novel in progress; about water and landscape, wet and dry; the second chapter of the novel called "Dried Water". And the strange process that accompanies a piece of deep research, incorporating all of you in its wake - the significant motif from the last lines of chapter two of my novel, as the character "Neelie" enters The Coorong, and trails her "somewhat smaller hand" in "the wake" of her memory. And I remembered, when I first discovered the soaked journal, how some part of me thought the washed away sentences so beautiful, like a rainwater colourist's painted landscape; a calligraphy, which had bled through the page. It was then that I saw it: when that day arrives, and I know my words in that way, when I re-know the imaginary landscape in my pages through and through; when it has seeped into me again, then I will know my subject, my imaginary landscape, from the inside out. I will have it blended and absorbed, like the smudging of sentences after rain, when ideas become fluid and begin to bleed together. Then the sentences will reveal their strange contribution, like the most original of exchanges: exchanges from within the first landscape of the semiotic world. 


\section{Acknowledgments}

I acknowledge the generous contribution that Ngarrindjeri Indigenous Educator Ms Veena Gollan and Ngarrindjeri Cultural Instructor Ms Stephanie Gollan have made to my fiction writing. I acknowledge the Ngarrindjeri weaver and Cultural Historian Ms Yvonne Koolmatrie, and thank her for her conversation and weaving at Tandanya, Adelaide, in March 2002. I would also like to thank the following people for their help in preparing this academic paper for publication: Dr Kevin Brophy and my joint supervisors Dr Christine Owen and Ms Sari Smith for their considered responses to the early draft; The University of Melbourne TRIPS, Dr Denise Varney and The School of Creative Arts for making research funds available to me. I am also grateful to my sister Ms Nicky Milte, for her liaison with Ngarrindjeri Indigenous Education colleagues, and for establishing some of my contacts in Adelaide.

\section{Notes}

1 'La Lumière du Sud-Ouest', Roland Barthes, Incidents, Translated by R. Howard, University of California Press, 1992, pp 3-9. Return to article

2 Yvonne Koolmatrie, Ngarrindjeri weaver and Cultural Historian, in conversation with the writer at Tandanya National Aboriginal Cultural Institute, Adelaide, 7 March 2002. Return to article

3 George Trevorrow in Ngarrindjeri Wurruwarrin: a world that is, was and will be, Diane Bell, Spinifex Press, 1998, Ch.5, 'A Land Alive: Embodying and Knowing the Country', p 249. Return to article

4 A Ngarrindjeri word, spoken to the writer and translated as: "My sister" by Ms Stephanie Gollan, Ngarrindjeri Cultural Instructor and weaver, at the Aboriginal Cultures Gallery, South Australian Museum, North Terrace, Adelaide, 4 July 2001. Return to article

5 Emily Dickinson, '832', in The Complete Poems, 1890. Return to article

6 Novel in progress, working title: Dissolve, Helen Milte Bastow, 2003. Return to article

7 For an illustrated guide to the Culture of the Ngarrindjeri People, see P. Jones, S. Hemming \& K. Clark Eds, Ngurunderi - An Aboriginal Dreaming, The South Australian Museum, 2000. Return to article

8 Barthes, pp 3-9. Return to article

9 Barthes, pp 8-9. Return to article

10 Julia Kristeva discusses some of these ideas from her theory of the semiotic in an illuminating interview with Susan Sellers in 'A Question of Subjectivity - an Interview', Women's Review, No 12, pp 19-21. For a theoretical explication of the relationship between depression, creativity and the semiotic, see Julia Kristeva, Black Sun Depression and Melancholia, Translated by Leon S. Roudiez, Columbia University Press, N.Y., 1989. Return to article

11 Milte Bastow, Dissolve, novel in progress. Return to article

12 Milan Kundera, The Art of the Novel, Translated by Linda Asher, Harper \& Row, 1986. Return to article

13 Kundera, pp 6-7. Return to article

14 Research Journal in process, Milte Bastow, p 1, 2003. Return to article

15 Kristeva, interview in Women's Review, pp 20-21. Return to article

16 Kristeva, interview in Women's Review, p 20. Return to article

17 Image photographed in the field by Milte Bastow, using an Olympus OM1camera, 100 ASA Kodak colour film, The Coorong, 1 July 2001. Return to article

18 The tour was out of Goolwa, run by the operators Spirit of The Coorong Cruises. The Ngarrindjeri have designated generous and spectacular walking ares for the tour, often into sensitive sites such as the vast midden collections. See the author's photographic images [images numbers 0 - 5]. Return to article

19 P. Jones, S. Hemming \& K. Clark, The South Australian Museum, 2000. Return to article

20 Veena Gollan's story, Veena Gollan, Adelaide, 2001. Return to article

21 For "a perceptive review of the modern history of the Aboriginal people of the Lower Murray lakes in South Australia", see Graham Jenkin, Conquest of the Ngarrindjeri - The Story Of The Lower Murray Lakes Tribes, 
Rigby Limited, 1979. Return to article

22 For further reading on the phenomenon of 'introjection', see Melanie Klein's theory of 'Object Relations', in The Selected Melanie Klein, Edited by Juliet Mitchell, Penguin, 1986. Return to article

23 Milte Bastow, Dissolve, novel in progress. This chapter is now "Chapter Three", to incorporate a new first chapter. Return to article

24 Lillian Holt, Director of Indigenous Studies, University of Melbourne; a phrase given in her Opening Address to the AAWP Dangerous Dreaming Conference, 22 November 2002. Return to article

25 I am improvising another journeying writer here, Walt Whitman, and his Romantic poem entitled 'Song of Myself' from Leaves of Grass. Return to article

26 P. Jones, S. Hemming \& K. Clark, The South Australian Museum, 2000. Return to article

27 a) The Australian Aboriginal Cultures Gallery at the South Australian Museum is a nationally and internationally important resource. The gallery has an outstanding collection of Ngarrindjeri cultural histories and artefacts, along with video-texts of the Ngarrindjerri Dreaming stories held in the adjacent Indigenous Information Centre. b) For an illustrated historical and cultural background of the Ngarrindjeri People, see Ngurunderi - An Aboriginal Dreaming - The Culture of the Ngarrindjeri People, The South Australian Museum, Editors P.Jones, S.Hemming \& K.Clark, 2000. c) Kaltja Now - Indigenous Arts Australia is an arts-based text published by the Wakefield Press in association with the National Aboriginal Cultural Institute in Adelaide - Tandanya. The publication contains an important essay on the internationally renowned work of the Ngarrindjeri weaver Ms.Yvonne Koolmatrie. d) The anthropologist Diane Bell's Ngarrindjeri Wurruwarrin: a world that is, was, and will be, is an "ethnography in the participant/observation mode"[ Review - Waters, NWSA Journal, Spring 2001]. The text contains a field-based collection of voices and testimonies from some prominent Ngarrindjeri women and men, many of them associated to the Goolwa gendered-mythology and Hindmarsh Island debate. e) Another resource for those interested in reading about The Coorong landscape and natural history is the National Parks and Wildlife Service's Coorong Park Notes available from the Department of Environment and Natural Resources, South Australia. Return to article

28 Milte Bastow, Research Journal in process, 4 July 2001. Return to article

29 The Australian Aboriginal Cultures Gallery at the South Australian Museum, North Terrace, Adelaide, curates an extensive collection of Ngarrindjeri cultural artefacts, including some examples of the "Sister Basket" woven from sedges. Visit: www.samuseum.sa.gov.au Return to article

30 Milte Bastow, Research Journal in process, 4 July 2001 Return to article

31 See Luce Irigaray, in This sex which is not one, Ch 4, 'The Power of Discourse and the Subordination of the Feminine', Translated by Catherine Porter, N.Y., Cornell University Press, 1988, p 73. Return to article

32 Kristeva, interview in Women's Review, p 20. Return to article

33 Gilles Deleuze, 'Literature and Life', Translated by D.W. Smith \& M.A. Greco, Critical Inquiry, Vol. 23, No 2, p 225. Return to article

34 Michael Leunig, Keynote Address to the Graduating Students, La Trobe University, 1999. Return to article

35 One of Ms.Stephanie Gollan's words used by her for "a little child". Return to article

\section{Bibliography}

Australian Aboriginal Cultures Gallery and Indigenous Information Centre, South Australian Museum, North Terrace, Adelaide.

Barthes, Roland. Incidents . Tr. R. Howard. L.A.: University of California Press, 1992.

Bell, Diane. Ngarrindjeri Wurruwarrin: a world that is, was, and will be. North Melbourne: Spinifex Press, 1998.

Chance, Ian (ed). Kaltja Now - Indigenous Arts Australia. Adelaide: Wakefield Press in association with The

National Aboriginal Cultural Institute - Tandanya, Adelaide, 2001.

Department of Environment and Natural Resources. Coorong Park Notes. Mallee Region: National Parks And Wildlife Service, 1996.

Deleuze, Gilles. 'Literature and Life. Tr. D.W. Smith \& M.A. Greco. Critical Inquiry 23, 2: 225.

Gollan, Veena. Veena Gollan's Story. Adelaide, 2001.

Irigaray, Luce. This sex which is not one. Tr. Catherine Porter. NY: Cornell University Press, 1988.

Jenkin, Graham. Conquest of the Ngarrindjeri - The Story Of The Lower Murray Lakes Tribes. Melbourne: Rigby, 1979.

Jones, P., Hemming, S. \& Clark, K. (eds). Ngurunderi An Aboriginal Dreaming - The Culture of the Ngarrindjeri People. Adelaide: South Australian Museum, 2000.

Klein, Melanie. The Selected Melanie Klein. Ed. Juliet Mitchell. Harmondsworth: Penguin, 1986. 
Kristeva, Julia. 'A Question of Subjectivity - an Interview'. Int. Susan Sellers. Women's Review Number 12. Kristeva, Julia. Black Sun - Depression and Melancholia. Tr. Leon S. Roudiez. NY: Columbia University Press, 1989.

Kundera, Milan. The Art of the Novel. Tr. Linda Asher. NY: Harper \& Row, 1986.

Helen Milte Bastow is a PhD candidate in the School of Creative Arts, University of Melbourne. Her short fiction has been accepted for publication in Quadrant (2003). In 1998 Helen was awarded the Emeritus Professor Derick Marsh Shakespeare Essay Prize for her Honours dissertation on King Lear. This paper was first presented at the Dangerous Dreaming AAWP Conference, held in the School of Creative Arts, University of Melbourne, 23 November 2002.

\section{TEXT}

Vol 7 No 1 April 2003

http://www.griffith.edu.au/school/art/text/

Editors: Nigel Krauth \& Tess Brady

Text@griffith.edu.au 